\title{
Laser ablation ICP-MS of size-segregated atmospheric particles collected with a MOUDI cascade impactor: a proof of concept
}

\author{
Marin S. Robinson ${ }^{1}$, Irena Grgic $\hat{c}^{2}$, Vid S. Šelih ${ }^{2}$, Martin Šala ${ }^{2}$, Marsha Bitsui ${ }^{1}$, and Johannes T. van Elteren ${ }^{2}$ \\ ${ }^{1}$ Department of Chemistry and Biochemistry, Northern Arizona University, P.O. Box 5698, Flagstaff, AZ 86011, USA \\ ${ }^{2}$ Department of Analytical Chemistry, National Institute of Chemistry, Slovenia, Hajdrihova 19, 1000 Ljubljana, Slovenia \\ Correspondence to: Johannes T. van Elteren (elteren@ki.si)
}

Received: 20 December 2016 - Discussion started: 13 February 2017

Revised: 11 April 2017 - Accepted: 24 April 2017 - Published: 16 May 2017

\begin{abstract}
A widely used instrument for collecting sizesegregated particles is the micro-orifice uniform deposit impactor (MOUDI). In this work, a 10-stage MOUDI (cutpoint diameter of $10 \mu \mathrm{m}$ to $56 \mathrm{~nm}$ ) was used to collect samples in Ljubljana, Slovenia, and Martinska, Croatia. Filters, collected with and without rotation, were cut in half and analyzed for nine elements ( $\mathrm{As}, \mathrm{Cu}, \mathrm{Fe}, \mathrm{Ni}, \mathrm{Mn}, \mathrm{Pb}, \mathrm{Sb}$, $\mathrm{V}, \mathrm{Zn}$ ) using laser ablation ICP-MS. Elemental image maps (created with ImageJ) were converted to concentrations using NIST SRM 2783. Statistical analysis of the elemental maps indicated that for submicron particles (stages 6-10), ablating $10 \%$ of the filter $\left(0.5 \mathrm{~cm}^{2}, 20 \mathrm{~min}\right.$ ablation time) was sufficient to give values in good agreement $( \pm 10 \%)$ to analysis of larger parts of the filter and with good precision (RSE $<1 \%)$. Excellent sensitivity was also observed (e.g., $20 \pm 0.2 \mathrm{pg} \mathrm{m}^{-3} \mathrm{~V}$ ). The novel use of LA-ICP-MS, together with image mapping, provided a fast and sensitive method for elemental analysis of size-segregated MOUDI filters, particularly for submicron particles.
\end{abstract}

\section{Introduction}

Inhalation of particle-bound metals in atmospheric particulate can negatively impact human health (Chen and Lippmann, 2009). Particle-bound $\mathrm{Fe}, \mathrm{Ni}$, and $\mathrm{V}$ can lead to oxidative stress, pulmonary inflammation, cardiac effects, and cardiovascular and respiratory illnesses (Aust et al., 2002; Bell et al., 2009; Campen et al., 2002). Particle size is also a factor. Submicron particles pose the greatest health risks (Davidson et al., 2005), and particle-bound metals from anthropogenic sources (e.g., fossil fuel combustion and ve- hicle emissions) commonly partition to these smaller sizes $(<1 \mu \mathrm{m})$ (Fang and Huang, 2011). A well-known instrument for the collection and speciation of size-segregated particles is the multi-orifice uniform deposit impactor (MOUDI) (Allen et al., 2001; Herner et al., 2006; Ntziachristos et al., 2007; Pekney et al., 2006; Singh et al., 2002). Particles are sorted by size into stages using cascade impaction and deposited on filters. Models with various flow rates (2$130 \mathrm{~L} \mathrm{~min}^{-1}$ ) and stages (cut-point diameter between 0.01 and $18 \mu \mathrm{m}$ ) are available, as well as rotating and non-rotating options (Marple, 1991; Marple et al., 2014). To determine elemental concentrations, filters are typically extracted with acid and analyzed by ICP-MS (Canepari et al., 2008; Herner et al., 2006; Li et al., 2012; Ntziachristos et al., 2007; Pekney et al., 2006) or ICP-AES (Fang and Huang, 2011), whereas in some cases direct analysis of the filters was performed by $\mathrm{X}$-ray fluorescence spectrometry ${ }^{11}$ or proton-induced X-ray emission (Brüggeman et al., 2009). Detection limits using these methods are challenging due to low particle mass and contamination risks; after corrections have been made for blanks, elemental concentrations are often below detection limits (Pekney et al., 2006).

A promising alternative to acid extraction involves laser ablation ICP-MS (LA-ICP-MS) (Aubriet and Carré, 2010). This method samples the filters via pulsed laser ablation, effectively removing the particles, thereby eliminating the need for harsh chemicals, offering faster sample preparation times, reducing contamination, and increasing sensitivity. Initial efforts using LA-ICP-MS have been promising (Gligorovski et al., 2008; Triglav et al., 2010), although problems associated with spatial inhomogeneity (Brown et al., 2009), matrixmatched standards (Chin et al., 1999; Tanaka et al., 1998), 
and laser instabilities have been reported. Hsieh et al. (2011) optimized the LA-ICP-MS parameters suitable for analysis of nanometer- and submicrometer-sized airborne particulate matter sampled by an electrical low-pressure impactor. In this work, we addressed these problems by using a MOUDI for particle collection and a highly stable excimer laser $(193 \mathrm{~nm}$ $\mathrm{ArF}^{*}$ ) for particle ablation. To our knowledge, we are the first to analyze MOUDI filters by LA-ICP-MS. Filters collected both with and without rotation were analyzed. Concentrations of nine elements from 10 MOUDI stages are reported with specific attention given to submicron particles (stages 6-10).

\section{Materials and methods}

\subsection{Air sampling}

A 10-stage, micro-orifice uniform-deposit impactor (MOUDI, model 110R with rotator, Applied Physics, Inc.) was used to collect four air samples where stages 110 correspond to $3,10,10,20,40,80,900,900,2000$, 2000 nozzles and $50 \%$ cut-point diameter of $10,5.6,3.2$, $1.8,1.0,0.56,0.32,0.18,0.10$, and $0.0156 \mu \mathrm{m}$, respectively. Samples 1 (24 h, 3 to 4 March 2015) and 2 (72 h, 31 March to 3 April 2015) were collected in a residential area of Ljubljana, Slovenia. Samples 3 (6 to 7 May 2015) and 4 (8 to 9 May 2015) were collected at Martinska station, Croatia, an estuary on the eastern Adriatic coast. Particles were collected on PTFE filters (Whatman, $46.2 \mathrm{~mm}$, deposit area $4.91 \mathrm{~cm}^{2}$ ). Samples 1, 2, and 4 were collected with rotation (depositing particles in concentric circles); sample 3 was collected without rotation (depositing particles in mounds or spots). The nominal flow rate was $30 \mathrm{~L} \mathrm{~min}^{-1}$.

\subsection{Laser ablation ICP-MS}

A quadrupole ICP-MS (Agilent Technologies 7900, Palo Alto, USA) interfaced with a laser ablation system $(193 \mathrm{~nm}$ ArF* excimer, Analyte G2, Teledyne Photon Machines, Inc.) was used to analyze nine nuclides $\left({ }^{75} \mathrm{As},{ }^{63} \mathrm{Cu},{ }^{57} \mathrm{Fe},{ }^{55} \mathrm{Mn}\right.$, ${ }^{60} \mathrm{Ni},{ }^{208} \mathrm{~Pb},{ }^{121} \mathrm{Sb},{ }^{51} \mathrm{~V},{ }^{66} \mathrm{Zn}$ ). (See optimized parameters in Table 1.) Ablation took place in a HelEx two-volume cell applying a laser beam size of $150 \mu \mathrm{m}$ (square mask), a scanning speed of $300 \mu \mathrm{m} \mathrm{s}^{-1}$, a repetition rate of $10 \mathrm{~Hz}$, and a fluence of $1.21 \mathrm{~J} \mathrm{~cm}^{-2}$. Ablated materials were transported from the ablation cell to the plasma with helium; argon was added as the make-up gas before the ICP torch. Ions formed in the plasma were extracted and separated by their mass-to-charge $(\mathrm{m} / \mathrm{z})$ ratios. The mass spectrometer, in time-resolved analysis mode, measured one point per mass for the nine selected masses. The detection limit for each element was determined as $3 \times \mathrm{SD}$ of seven clean blanks (Table 2 ).
Table 1. Optimized operating conditions for the laser ablation ICPMS system.

\begin{tabular}{|c|c|}
\hline \multicolumn{2}{|l|}{ Laser ablation (Analyte G2) } \\
\hline Wavelength & 193 \\
\hline Pulse length & $<4 \mathrm{~ns}$ \\
\hline Beam size (square mask) & $150 \mu \mathrm{m}$ \\
\hline Fluence & $1.21 \mathrm{~J} \mathrm{~cm}^{-2}$ \\
\hline Repetition rate & $10 \mathrm{~Hz}$ \\
\hline Scanning speed & $300 \mu \mathrm{m} \mathrm{s}^{-1}$ \\
\hline He carrier flow rate & $\begin{array}{l}0.5 \mathrm{Lmin}^{-1} \text { (cup) and } \\
0.3 \mathrm{Lmin}^{-1} \text { (cell) }\end{array}$ \\
\hline Ar make-up flow rate & $0.8 \mathrm{Lmin}^{-1}$ \\
\hline \multicolumn{2}{|l|}{ ICP-MS (Agilent 7900) } \\
\hline Radio frequency power & $1500 \mathrm{~W}$ \\
\hline Sampling depth & $9 \mathrm{~mm}$ \\
\hline Acquisition time/mass & $0.5-1.0 \mathrm{~s}$ \\
\hline Measurement mode & time-resolved TRA(1) \\
\hline Ar plasma gas flow rate & $15 \mathrm{Lmin}^{-1}$ \\
\hline Ar auxiliary gas flow rate & $0.7 \mathrm{~L} \mathrm{~min}^{-1}$ \\
\hline $\begin{array}{l}\text { No. of line scans/mapping } \\
\text { sequence }\end{array}$ & $\begin{array}{l}70-150(0.56-4.38 \mathrm{~min} \\
\left.\text { line } \operatorname{scan}^{-1}\right)\end{array}$ \\
\hline Isotopes measured & $\begin{array}{l}{ }^{75} \mathrm{As},{ }^{63} \mathrm{Cu},{ }^{57} \mathrm{Fe},{ }^{55} \mathrm{Mn},{ }^{60} \mathrm{Ni}, \\
{ }^{208} \mathrm{~Pb},{ }^{121} \mathrm{Sb},{ }^{51} \mathrm{~V},{ }^{66} \mathrm{Zn}\end{array}$ \\
\hline
\end{tabular}

Table 2. Detection limits (DLs; $3 \times \mathrm{SD}$ ) were determined from the mean standard deviations of seven clean blanks with ablation areas of $1.1 \mathrm{~cm}^{2}$. DLs were converted to concentrations using the NIST standard and a theoretical air sampling period of $24 \mathrm{~h}$ at $30 \mathrm{~L} \mathrm{~min}^{-1}$. All values were spike corrected. Units are in $\mathrm{ng} \mathrm{m}^{-3}$.

\begin{tabular}{lr}
\hline Element & DL \\
\hline $\mathrm{As}$ & 0.019 \\
$\mathrm{Cu}$ & 0.009 \\
$\mathrm{Fe}$ & 0.370 \\
$\mathrm{Mn}$ & 0.016 \\
$\mathrm{Ni}$ & 0.114 \\
$\mathrm{~Pb}$ & 0.004 \\
$\mathrm{Sb}$ & 0.019 \\
$\mathrm{~V}$ & 0.003 \\
$\mathrm{Zn}$ & 0.160 \\
\hline
\end{tabular}

\subsection{Filter preparation and ablation}

All 10 filters (stages 1-10) were ablated in samples 1 and 2 (Ljubljana, rotation), eight filters (stages 3-10) were ablated in sample 3 (Martinska, non-rotation), and four filters (samples 6-9) were ablated in sample 4 (Martinksa, rotation). Filters were cut in half and four or five were co-mounted on a single glass slide with double-sided tape (Fig. 1). For the rotated filters (Fig. 1a), the laser raster pattern comprised parallel lines that spanned the width and ran the length of the co-mounted half filters. For the non-rotated filters (Fig. 1b), 


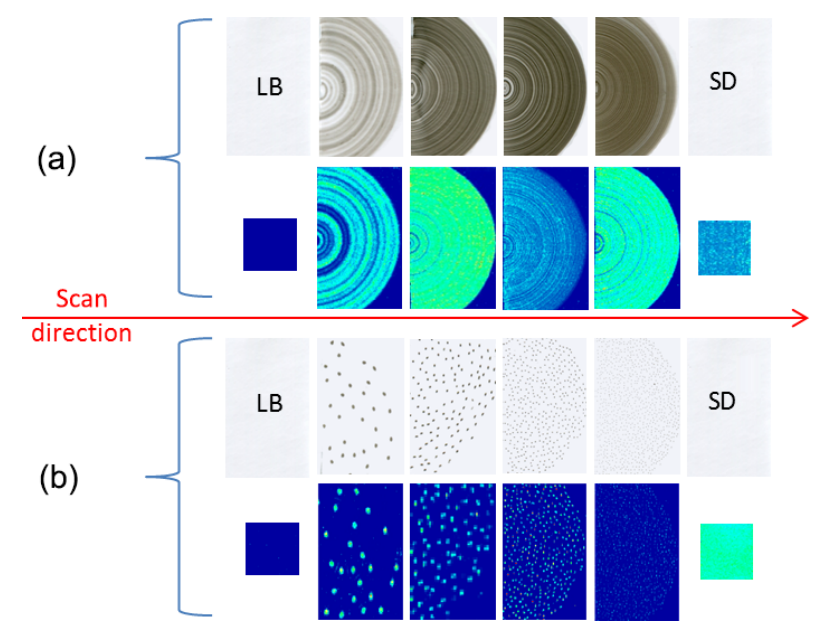

Figure 1. Setups for LA-ICP-MS of rotated (a, sample 1, stages 710) and non-rotated (b, sample 3, stages 6-9) filters; both optical and elemental images (pseudocolored image maps of $\mathrm{Pb}$ ) for each filter are shown. Lab blanks (LB) and the NIST 2783 standard (STD) were analyzed next to the filters.

half filters were ablated individually, except for stages 3 and 4 , which were ablated spot by spot ( 5 of 10 spots in stage 3 ; 9 of 20 spots in stage 4). A standard reference material (NIST 2783, air particulate on filter media) with certified elemental areal mass densities $\left(\mathrm{ng} \mathrm{cm}^{-2}\right)$ and a lab blank (an unexposed filter, taken directly from the box) were mounted alongside the exposed filters. At least $1 \mathrm{~cm}^{2}$ of the NIST and blank filters were ablated with each set of four or five half filters. LA-ICP-MS stability was tested by ablating the NIST standard in four segments $\left(0.25 \mathrm{~cm}^{2}\right.$ per segment), alternating with the sample filters. No loss in laser stability or ICPMS drift was observed over $11 \mathrm{~h}$.

The laser beam energy was sufficient to remove several layers of the PTFE filter in each particle size range, and no particles were visible on the filters $(100 \times$ magnification $)$ following ablation; hence, we assume that most particles were removed during ablation. However, deeply impacted particles may have remained embedded in the filters, particularly for the smaller particles in the case of MOUDI sampling without rotation and high loading. Elemental concentrations were determined via one-point calibration with the NIST standard.

\subsection{Quality assurance and quality control}

Filters from sample 1 (stages 6-10) were cut in half and analyzed by laser ablation and wet-chemical ICP-MS (Agilent Technologies 7900). For wet-chemical analysis, standards were prepared by diluting certified, traceable, inductively coupled plasma-grade, single-element standards. Filters were placed in metal-free HDPE vials containing $10 \mathrm{~mL}$ of an acid mixture $\left(5 \% \mathrm{HNO}_{3}\right.$ and $\left.2.5 \% \mathrm{HCl}, v / v\right)$, mixed by a rotary shaker for $12 \mathrm{~h}$, and centrifuged. Extracts were measured
Table 3. Correlation coefficient $(R)$ and slope $(m$ in $y=m x)$ for concentrations measured by laser ablation ICP-MS $(x)$ and wetchemical ICP-MS $(y)$ in MOUDI stages 6-10. Reasonable agreement was observed for the first six elements.

\begin{tabular}{lrr}
\hline Element & $R$ & $m$ \\
\hline $\mathrm{As}$ & 0.97 & 0.92 \\
$\mathrm{Fe}$ & 0.99 & 1.52 \\
$\mathrm{Mn}$ & 0.97 & 0.93 \\
$\mathrm{~Pb}$ & 0.98 & 0.91 \\
$\mathrm{~V}$ & 0.99 & 0.83 \\
$\mathrm{Zn}$ & 0.95 & 0.92 \\
$\mathrm{Cu}$ & 0.78 & 1.08 \\
$\mathrm{Ni}$ & 0.03 & 2.20 \\
$\mathrm{Sb}$ & 0.52 & 0.23 \\
\hline
\end{tabular}

without dilution. Recovery rates (85-105\%) were measured using NIST SRM 2783 as a reference standard. Good agreement was observed between wet-chemical and laser ablation ICP-MS for $\mathrm{As}, \mathrm{Fe}, \mathrm{Mn}, \mathrm{Pb}, \mathrm{V}$, and $\mathrm{Zn}(R=0.94-0.99$; $m=0.83-1.52$ ). Poor agreement was observed for $\mathrm{Cu}, \mathrm{Ni}$, and $\mathrm{Sb}$, attributed in part to low concentration levels in the extracts (low $\mu \mathrm{g} \mathrm{L}^{-1}$ ) (Table 3).

\section{Results and discussion}

\subsection{Elemental image maps}

Unlike wet-chemical ICP-MS (a bulk technique), LA-ICPMS allows for microanalysis of solid samples. In this work, each laser pulse provided spatially resolved elemental data (in counts per second associated with a certain $m / z$ value). Using ImageJ software (Schneider et al., 2012), these data were mapped into pixels. The pixels formed elemental image maps with pixel size $P_{\text {size }}\left(\mu \mathrm{m}^{2}\right)$ :

$P_{\text {size }}=\mathrm{ss} \times t_{\text {acq }} \times d$,

where ss is the laser scanning speed $\left(\mu \mathrm{ms}^{-1}\right), t_{\mathrm{acq}}$ is the ICP-MS acquisition time (s), and $d$ is the laser beam dimension $(\mu \mathrm{m})$. To obtain maps with square pixels we selected a scanning speed and an acquisition time so that $\mathrm{ss} \times t_{\mathrm{acq}}=$ $d$; hence, $P_{\text {size }}=d^{2}$. In this work, $P_{\text {size }}=150 \times 150 \mu \mathrm{m}^{2}$ ( $\mathrm{ss}=300 \mu \mathrm{m} \mathrm{s}^{-1}, t_{\mathrm{acq}}=0.5 \mathrm{~s}, d$ [square mask] $\left.=150 \mu \mathrm{m}\right)$. For an analyzed area $A_{\text {anal }}\left(\mathrm{cm}^{2}\right)$, the number of pixels $P$ is given by $10^{8} \times A_{\text {anal }} / d^{2}$.

For our half filters, $A_{\text {anal }}$ was nominally $2.4 \mathrm{~cm}^{2}$ or 10677 pixels $\left(1 \mathrm{~cm}^{2}=4444\right.$ pixels $)$. Image maps for $\mathrm{Pb}$ are shown in Fig. 1a (sample 1, rotated filters of stages 7-10) and Fig. 1b (sample 3, non-rotated filters of stages 6-9). (See Figs. S1 and S2 in the Supplement for maps of other elements in samples 1 and 3, respectively.) The false image map colors in Fig. 1 are brightness values, where each pixel $i$ with element intensity $I_{i}$ is converted by Image J to a brightness value 
$B_{i}$ (dimensionless) using 65536 pseudocolors (or 65536 levels of gray).

\subsection{Visual inspection of elemental maps}

Elemental image maps offer a robust tool for observing details about particle deposition not detectable by bulk methods. For example, the 2-D image maps in Fig. 1a illustrate the concentric circles created by MOUDI rotation. A clogged nozzle is apparent in stage 7, where minimal deposition is observed near the center of the half filter. Other images made apparent a thumb print, a scissors cut, and the edge of the mounting tape. The ability to "see" such errors made it straightforward to avoid these parts of the filter when selecting areas to analyze. The maps also offered insights into the deposition patterns of various elements. Most notable was $\mathrm{Ni}$, which, unlike other elements, deposited in mounds even when collected with rotation (Fig. S3).

Additional information can be gleaned from 3-D image maps. For example, 3-D maps of non-rotated filters gave direct evidence for particle bounce (Marple et al., 2014). Relative intensities, measured with ImageJ, indicated that $12 \%$ of the signal for $\mathrm{Pb}$ (stage 5) was located between spots (Fig. S4). Bounce was less pronounced in stages 6-10 (due to more nozzles). Three-dimensional maps also made apparent "spikes" in the data, defined as values more than twice the median. Spikes were observed for most elements in sample filters (rotated), filter blanks, and gas blanks. In each case, outliers were replaced with the median of the pixels in the surrounding area $(2 \times$ pixel size). This correction was made in all filters (including blanks) except for non-rotated filters, where the much higher concentrations in the spots masked the spikes. Spike removal is illustrated in Fig. S5 for $\mathrm{Zn}$ (stages 6-10). After spike removal, the average relative standard deviation of the mapped area decreased from 300 to $30 \%$.

\subsection{Statistical analysis of elemental maps}

The elemental brightness values associated with each pixel were analyzed statistically using ImageJ (after spike removal). First, we investigated how small an area could be ablated and still reproduce the mean half-filter value $B_{\text {half }}$. We measured (for rotated filters) mean elemental areal brightness values, $B_{\text {areal }}\left(\mathrm{cm}^{-2}\right)=\sum B_{i} / A_{\text {anal }}$, for successively smaller areas $A_{\text {anal }}$ (generally rectangular shapes, in different sections of the half filter) and compared them to $B_{\text {half. For }}$ stages $6-10,10 \%$ of the total filter deposit area $\left(0.5 \mathrm{~cm}^{2}\right.$, $20 \mathrm{~min}$ ablation time) gave brightness values in good agreement $( \pm 10 \%)$ to the half-filter values. Representative results for Pb (sample 1, stages 7-9) are shown in Fig. 2. For stages $1-5,20 \%$ of the filter deposit area $\left(1 \mathrm{~cm}^{2}, 40 \mathrm{~min}\right.$ ablation time) gave similar results. A notable exception was $\mathrm{Ni}$, which had irregular deposition (Fig. S3). For non-rotated filters (without spike removal), good agreement $( \pm 10 \%)$ to

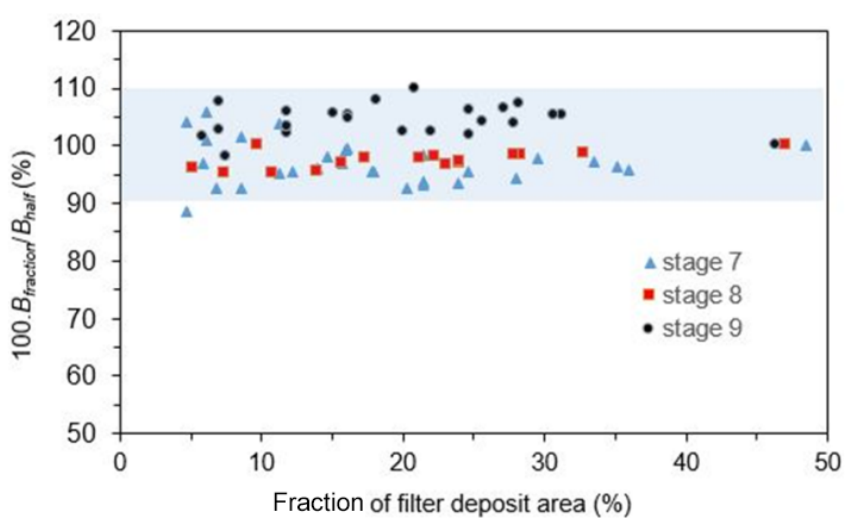

Figure 2. Comparison of mean brightness values for smaller ablation areas $\left(B_{\text {fraction }}\right)$ to the half-filter value $\left(B_{\text {half }}\right)$ for $\mathrm{Pb}$ in sample 1 (stages 7-9). The blue bar shows that ablation of smaller areas agreed with the half-filter value to $\pm 10 \%$.

$B_{\text {half }}$ was observed when (a) at least $15 \%$ of the total deposit area was ablated in stages 7-10 and (b) areas containing 5 spots (of 40) and 8 spots (of 80), respectively, were ablated in stages 5 and 6 . In stages 3 and 4, where individual spots were ablated, we measured only the relative standard deviations across spots: $25 \%(n=5)$ and $23 \%(n=9)$, respectively.

Second, for rotated filters, where deposition is expected to be uniform, we measured the relative standard deviations (RSD) of the elemental areal brightness values for each MOUDI stage (after spike removal). For stages 1 to 3, RSD values were large (120 to $80 \%$, respectively) due to fewer particles and fewer nozzles at those stages. RSD values decreased in stage $4(60 \%)$, stage $5(40 \%)$, and stages $6-10$ (all $\sim 30 \%$ ). RSD values became constant at larger areas (more pixels); hence, relative standard error (RSE) values $(=\mathrm{RSD} / \sqrt{ }$ (number of pixels)) were also determined. Results are shown in Fig. 3, where both theoretical and experimental RSE values for $\mathrm{Pb}$ (sample 1) are plotted. For stage 4, an ablation area of $20 \%\left(1 \mathrm{~cm}^{2}, 40\right.$ min ablation time $)$ was sufficient for good precision (RSE $=1 \%$ ); for stages $5-10$, only $10 \%$ was required $\left(0.5 \mathrm{~cm}^{2}, 20 \mathrm{~min}\right.$ ablation time $)$. In contrast to our previous findings (Gligorovski et al., 2008), in this work the NIST standard also showed good precision for a $1 \mathrm{~cm}^{2}$ (4444 pixels) ablation area $(\mathrm{RSD}=22 \%$, $\mathrm{RSE}=0.33 \%)$.

\subsection{Elemental concentrations}

Like wet-chemical ICP-MS, the ultimate goal of LA-ICPMS is to measure elemental concentrations. Elemental image maps were converted to concentrations using the NIST standard. For rotated filters, $B_{\text {areal }}\left(\mathrm{cm}^{-2}\right)$ was converted to a mass density $M_{\text {areal }}\left(\mathrm{ng} \mathrm{cm}^{-2}\right)$ using $B_{\text {areal,NIST }}$ and $M_{\text {areal,NIST }}$ (Eq. 2). $B_{\text {areal }}$ values were blank corrected using 


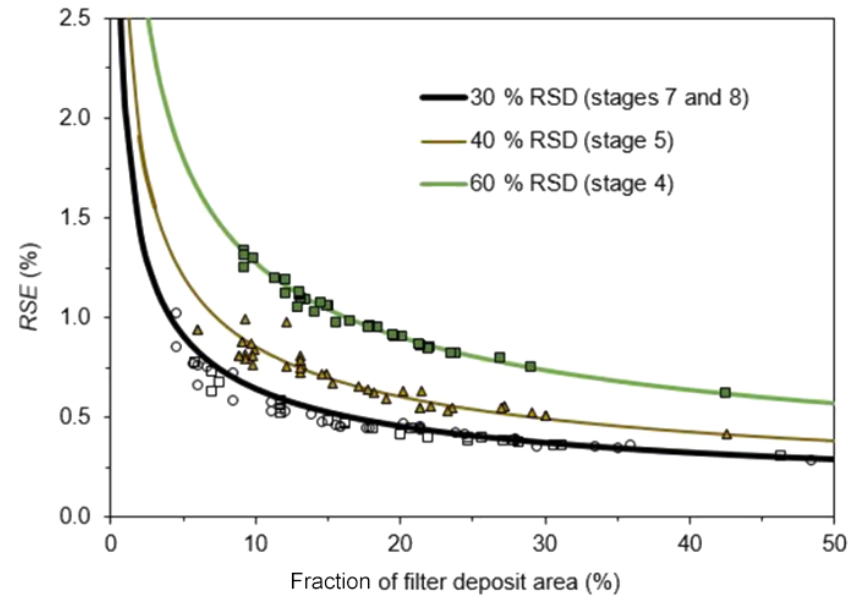

Figure 3. Relative standard errors $(\mathrm{RSE}=\mathrm{RSD} / \sqrt{ } P)$ as a fraction of the number of pixels $P(=21822$ pixels, associated with a total filter deposit area $A_{\text {tot }}$ of $4.91 \mathrm{~cm}^{2}$ ). Solid lines are theoretical values for $\mathrm{RSD}=30,40$, and $60 \%$. Markers are experimental values for $\mathrm{Pb}$ in stages 4 (filled squares), 5 (filled triangles), and 7 and 8 (open squares and circles).

the average elemental areal brightness value of seven clean blanks $B_{\text {areal,BL: }}$

$M_{\text {areal }}=\frac{B_{\text {areal }}-B_{\text {areal }, \mathrm{BL}}}{\frac{B_{\text {areal }, \mathrm{NIST}}}{M_{\text {areal }, \mathrm{NIST}}}}$.

Atmospheric elemental concentrations $C_{\text {air }}\left(\mathrm{ng} \mathrm{m}^{-3}\right)$ were determined by multiplying $M_{\text {areal }}$ by the filter exposure area $\left(4.91 \mathrm{~cm}^{2}\right)$ and dividing by the air volume $\left(43.2 \mathrm{~m}^{3}\right)$. Although half-filter areas were used in these calculations, as shown above, $10 \%$ areas (stages 6-10) or $20 \%$ areas (stages 1-5) gave comparable results $( \pm 10 \%)$. A corresponding approach was used for non-rotated filters, except that spikes were not removed. Also, in stages 3 and 4, elemental brightness values were determined per spot rather than per area, then multiplied by the total number of spots per filter.

Atmospheric elemental concentrations were highest in MOUDI stages 5-9 (1.0-0.1 $\mu \mathrm{m})$; these concentrations are shown in Fig. 4a (Ljubljana, samples 1 and 2) and 4B (Martinska, samples 3 and 4). (See Tables S1 and S2 for all concentrations.) Elemental concentrations $\left(\mathrm{ng} \mathrm{m}^{-3}\right)$ are shown on the left; percentages (normalized to $100 \%$ ) are shown on the right. To facilitate comparison, the two Ljubljana samples (24 and $72 \mathrm{~h}$ ) and the two Martinksa samples (both $24 \mathrm{~h}$ ) are plotted side by side. Together, these graphs illustrate both the magnitude and relative contributions of the nine elements in each stage. Several trends are worth noting. First, at both sites, the largest concentrations were observed in stage 5 (cut point $=1 \mu \mathrm{m}$ ). In Ljubljana, the $24 \mathrm{~h}$ concentrations were generally greater than the $72 \mathrm{~h}$ values (except for stage 5), but the relative percentages in each stage were quite similar. These trends suggest a common major source for the elements, but one that varies in magnitude from day to day. Consistent with previous works (Grgić et al., 2009; Hitzenberger et al., 2006; Mirage, 1989; Pacyna and Pacyna, 2001), we attribute this source to traffic emissions. Fe and $\mathrm{Zn}$ were the major elements comprising $85 \%$ of the total elemental mass in sample $1\left(101 \mathrm{ng} \mathrm{m}^{-3} \mathrm{Fe}\right.$; $44 \mathrm{ng} \mathrm{m}^{-3} \mathrm{Zn}$ ) and $90 \%$ of the total elemental mass in sample $2\left(127 \mathrm{ng} \mathrm{m}^{-3} \mathrm{Fe} ; 27 \mathrm{ng} \mathrm{m}^{-3} \mathrm{Zn}\right)$. The other trace elements (e.g., $\mathrm{Cu}, \mathrm{Pb}, \mathrm{V}$, and $\mathrm{Mn}$ ) were also consistent with traffic emissions and vehicle exhaust or fossil fuel or biomass combustion (Mirage, 1989; Pacyna and Pacyna, 2001). We note the excellent sensitivity that was observed in detecting trace metals with $24 \mathrm{~h}$ concentrations as low as $20( \pm 0.2), 22$ $( \pm 0.2)$, and $26( \pm 0.1) \mathrm{pg} \mathrm{m}^{-3}$ for $\mathrm{V}$ (stage 9), Mn (stage 10), and As (stage 10), respectively.

In Martinska (Fig. 4b), the total elemental concentrations were lower than in Ljubljana by roughly a factor of 2 . The highest values were in stage $5\left(36 \mathrm{ng} \mathrm{m}^{-3}\right)$, predominated by $\mathrm{Fe}(92 \%)$ with smaller amounts of $\mathrm{Zn}(3 \%), \mathrm{Mn}(2 \%), \mathrm{Pb}$ $(1 \%)$, and $\mathrm{V}(1 \%)$. In general, higher total concentrations were observed in sample 4 (day 2), and there was more variability in composition between the 2 days than in Ljubljana. The largest variability was observed for $\mathrm{V}$ in stage 8 ; concentrations varied from $1.92(39 \%)$ in sample 3 (day 1) to $1.36 \mathrm{ng} \mathrm{m}^{-3}(14 \%$ ) in sample 4 (day 2). Vanadium has been observed previously in marine aerosols (Turšič et al., 2006) and is attributed to continental pollution from oil combustion (Tolocka et al., 2004). The variability in the direction of continental winds on the 2 days of sampling may have influenced this signal.

\section{Conclusions}

In this proof-of-concept paper, we have demonstrated the usefulness of LA-ICP-MS as a tool for analyzing the elemental composition of size-segregated atmospheric particles collected on filter-based media. Previous problems associated with LA-ICP-MS were addressed: (1) MOUDI rotation sampling overcomes the lack of uniformity in particle deposition, creating a sample highly suitable for LA-ICP-MS 2 D mapping; (2) the 2-D mapping mode yields results which show a high degree of accuracy when larger areas are ablated and superior detection limits; and (3) quantification problems due to non-matrix matched standards are circumvented by ablating through the filter or obliterating the particles on the filters, warranting the reliable use of one-point calibrating on NIST SRM 2783. Together, these improvements allowed for an efficient and sensitive measurement of elemental composition. Although half filters were analyzed in much of this work, we showed that comparable results could be obtained by ablating only $1 \mathrm{~cm}^{2}$ of filter or less. The ability to analyze a filter in roughly $40 \mathrm{~min}$ of instrument time makes feasible routine measurements of size-segregated par- 
(a) Ljubljana (samples 1 and 2)
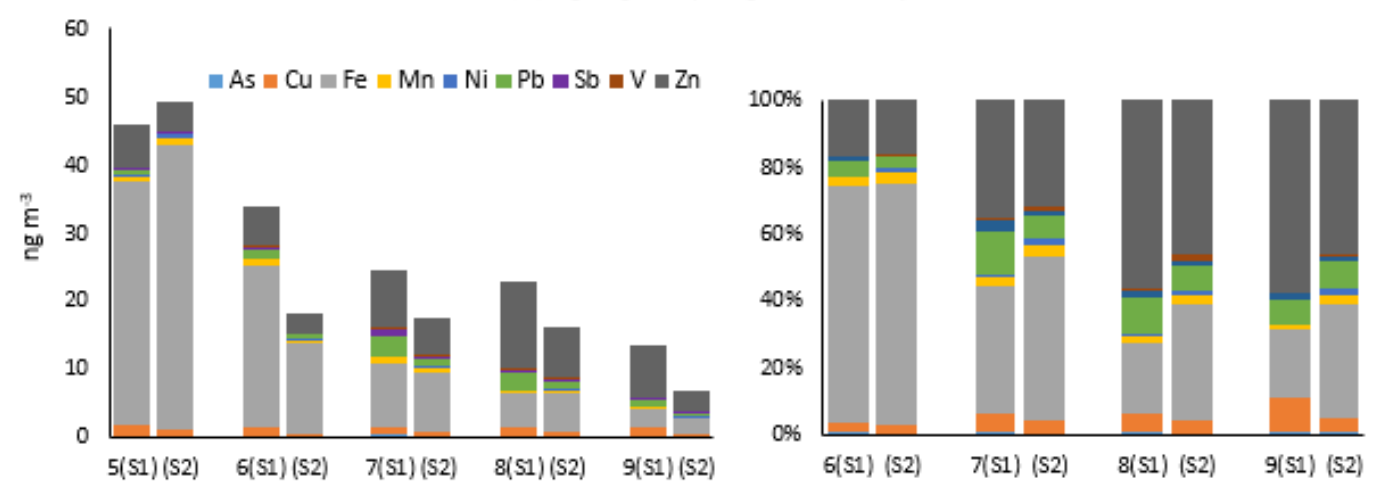

(b) Martinska (samples 3 and 4)
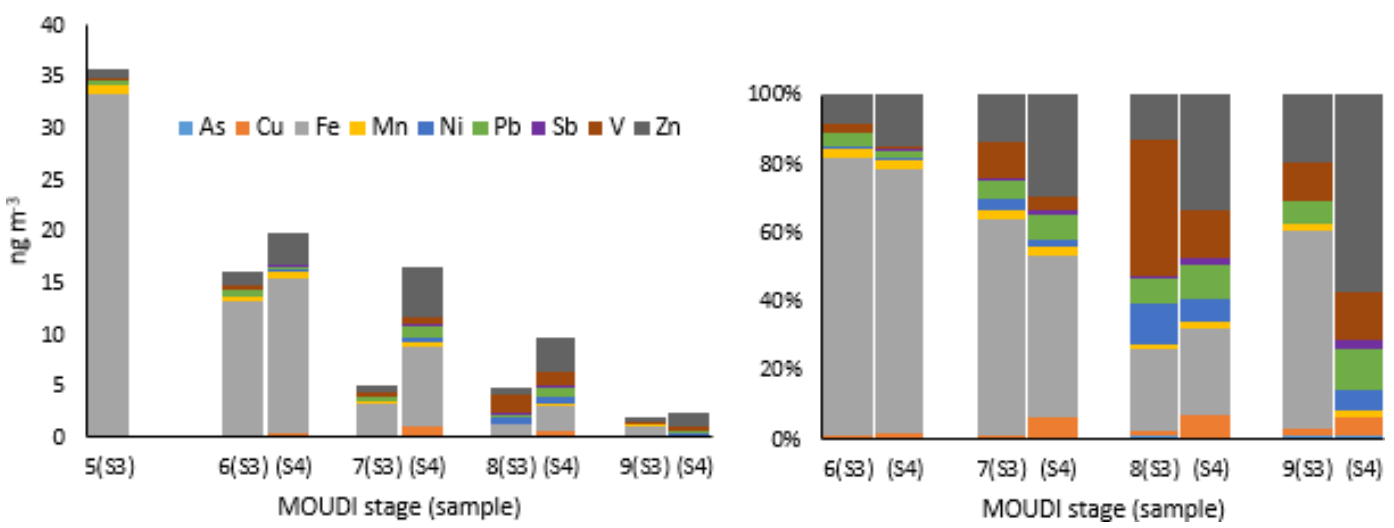

Figure 4. Elemental concentrations of (a) samples 1 (24h) and 2 (72 h) in Ljubljana and (b) samples 3 (24h) and 4 (24h) in Martinska. Graphs on the left show atmospheric concentrations. Graphs on the right show corresponding percent composition. MOUDI stages 5-9 correspond to cut-point diameter of $1.0,0.56,0.32,0.18$, and $0.10 \mu \mathrm{m}$, respectively.

ticles. Compositional graphs of these particles, such as those shown in Fig. 4 for Ljubljana and Martinska, will be useful to the atmospheric community by allowing comparison of elemental profiles of particulate collected at diverse sites (e.g., urban industrial centers to remote background locations). Such profiles can be compared over days, months, or even years; short-term and long-term compositional changes can be used to monitor atmospheric changes such as a new pollution source, the impacts of pollution remediation, and the effects of climate change. A key limitation to this approach is the lack of a size-segregated reference standard; hence, measurement of absolute elemental concentrations is not yet feasible. Nonetheless, much can be learned from relative changes in elemental composition, which are easily measured by this technique.

Data availability. Experimental data presented in this work are available upon request (Johannes T. van Elteren: elteren@ki.si).

\section{Information about the Supplement}

The Supplement includes (1) atmospheric elemental concentrations for MOUDI stages 1-5 (Table S1) and 6-10 (Table S2), (2) elemental image maps for stages 6-10 of sample 1 (Fig. S1), (3) elemental image maps for stages 6 and 9 of sample 2 ("spots") (Fig. S2), (4) elemental image maps of $\mathrm{Ni}$ vs. $\mathrm{Pb}$ (Fig. S3, stages 3-8), (5) illustration of particle bounce for $\mathrm{Pb}$ (Fig. S4), and (6) illustration of spike removal for zinc (Fig. S5, stages 6-10, sample 1).

\section{The Supplement related to this article is available online at doi:10.5194/amt-10-1823-2017-supplement.}

Author contributions. M. S. Robinson collected samples, carried out experiments, and prepared the manuscript. V. S. Šelih and M. Šala carried out experiments. I. Grgić collected samples and prepared the manuscript. M. Bitsui collected samples. J. T. van Elteren designed and carried out experiments and prepared the manuscript. 
Competing interests. The authors declare that they have no conflict of interest.

Acknowledgements. This work was funded by the Slovenian Research Agency (contract no. P1-0034) and the Fulbright Scholar Program, sponsored by the US Department of State, administered by CIES, a division of IIE. The authors thank Sanja Frka Milosavljević for arranging access to Martinska station.

Edited by: P. Herckes

Reviewed by: V. Carre and one anonymous referee

\section{References}

Allen, A. G., Nemitz, E., Shi, J. P., Harrison, J. P., and Greenwood, J. C.: Size distributions of trace metals in atmospheric aerosols in the United Kingdom, Atmos. Environ., 42, 4581-4591, 2001.

Aubriet, F. and Carré, V.: Potential of laser mass spectrometry for the analysis of environmental dust particles - A review, Anal. Chim. Acta, 659, 34-54, 2010.

Aust, A. E., Ball, J. C., Hu, A. A., Lighty, J. S., Smith, K. R., Straccia, A. M., Veranth, J. M., and Young, W C., Particle characteristics responsible for effects on human lung epithelial cells, Res. Rep. Health Eff. Inst., 110, 1-65, 2002.

Bell, M. L., Ebisu, K., Peng, R. D., Samet, J. M., and Dominici, F.: Hospital admissions and chemical composition of fine particle air pollution, Am. J. Resp. Crit. Care, 179, 1115-1120, 2009.

Brown, R. J. C., Jarvis, K. E., Disch, B. A., Goddard, S. L., and Brown, A. S.: Spatial inhomogeneity of metals in particulate matter on ambient air filters determined by LA-ICP-MS and comparison with acid digestion ICP-MS, J. Environ. Monit., 11, 2022-2029, 2009.

Brüggemann, E., Gerwig, H., Gnauk, T., Müller, K., and Herrmann, $\mathrm{H}$.: Influence of seasons, air mass origin and day of the week on size-segregated chemical composition of aerosol particles at a kerbside, Atmos. Environ., 43, 2456-2463, 2009.

Campen, M. J., Nolan, J. P., Schladweiler, M. C., Kodavanti, U. P., Costa, D. L., and Watkinson, W. P.: Cardiac and thermoregulatory effects of instilled particulate matter-associated transition metals in healthy and cardiopulmonary-compromised rats, J. Toxicol. Env. Heal. A, 65, 1615-1631, 2002.

Canepari, S., Perrino, C., Olivieri, F., and Astolfi, M. L.: Characterisation of the traffic sources of PM through size-segregated sampling, sequential leaching and ICP analysis, Atmos. Environ., 42, 8161-8175, 2008.

Chen, L. C. and Lippmann, M.: Effects of metals within ambient air particulate matter (PM) on human health, Inhal. Toxicol., 1, 11-31, 2009.

Chin, C.-J., Wang, C.-F., and Jeng, S.-L.: Multi-element analysis of airborne particulate matter collected on PTFE-membrane filters by laser ablation inductively coupled plasma mass spectrometry, J. Anal. Atom. Spectrom., 14, 663-668, 1999.

Davidson C. I., Phalen, R. F., and Solomon, P. A.: Airborne particulate matter and human health: A review, Aerosol Sci. Technol., 39, 737-749, 2005.
Fang, G.-C. and Huang, C.-S., Atmospheric particulate and metallic elements $(\mathrm{Zn}, \mathrm{Ni}, \mathrm{Cu}, \mathrm{Cd}$ and $\mathrm{Pb}$ ) size distribution at three characteristic sampling sites, Environ. Forensics, 12, 191-199, 2011.

Gligorovski, S., van Elteren, J. T., and Grgić, I.: A multi-element mapping approach for size-segregated atmospheric particles using laser ablation ICP-MS combined with image analysis, Sci. Total Environ., 407, 594-602, 2008.

Grgić, I., Turšič, J., and Berner, A.: Applying size segregation to relate the surrounding aerosol pollution to its source, J. Atmos. Chem., 63, 247-257, 2009.

Herner, J. D., Green, P. G., and Kleeman, M. J.: Measuring the trace elemental composition of size-resolved airborne particles, Environ. Sci. Technol., 40, 1925-1933, 2006.

Hitzenberger, R., Ctyroky, P., Berner, A., Turšič, J., Podkrajšek, B., and Grgić, I.: Size distribution of black (BC) and total carbon (TC) in Vienna and Ljubljana, Chemosphere, 65, 2106-2113, 2006.

Hsieh, Y.-K., Chen, L.-K., Hsieh, H.-F., Huang, C.-H., and Wang, C.-F.: Elemental analysis of airborne particulate matter using an electrical low-pressure impactor and laser ablation/inductively coupled plasma mass spectrometry, J. Anal. Atom. Spectrom., 26, 1502-1508, 2011.

Li, X., Wang, L., Wang, Y., Wen, T., Yang, Y., Zhao, Y., and Wang, Y.: Chemical composition and size distribution of airborne particulate matters in Beijing during the 2008 Olympics, Atmos. Environ., 50, 278-286, 2012.

Marple, V.: A micro-orifice uniform deposit impactor (MOUDI): Description, calibration, and use, Aerosol Sci. Technol., 14, 434446, 1991.

Marple, V., Olson, B., Romay, F., Hudak, G., Geerts, S. M., and Lundgren, D.: Second generation micro-orifice uniform deposit impactor, 120 MOUDI-II: Design, evaluation, and application to long-term ambient sampling, Aerosol Sci. Technol., 48, 427433, 2014.

Mirage, J. O.: A global assessment of natural sources of atmospheric trace metals, Nature, 338, 47-49, 1989.

Ntziachristos, L., Ning, Z., Geller, M. D., Sheesley, R. J., Schauer, J. J., and Sioutas, C.: Fine, ultrafine, and nanoparticle trace element compositions near a major freeway with a high heavy-duty diesel fraction, Atmos. Environ., 41, 5684-5696, 2007.

Pacyna, J. M. and Pacyna, E. G., An assessment of global and regional emissions of trace metals to the atmosphere from anthropogenic sources worldwide, Environ. Rev., 9, 269-298, 2001.

Pekney, N. J., Davidson, C. I., Bein, K. J., Wexler, A. S., and Johnston, M. V.: Identification of sources of atmospheric PM at the Pittsburgh Supersite, Part I: Single particle analysis and filterbased positive matrix factorization, Atmos. Environ., 40, 411423, 2006.

Schneider, C. A., Rasband, W. S., and Eliceiri, K. W.: NIH Image to ImageJ: 25 years of image analysis, Nat. Methods, 9, 671-675, 2012.

Singh, M., Jaques, P. A., and Sioutas, C.: Size distribution and diurnal characteristics of particle-bound metals in source and receptor sites of the Los Angeles Basin, Atmos. Environ., 36, 16751689, 2002.

Tanaka, S., Yasushi, N., Sato, N., Fukasawa, T., Santosa, S. J., Yamanaka, K., and Ootoshi, T.: Rapid and simultaneous multielement analysis of atmospheric particulate matter using inductively coupled plasma mass spectrometry with laser ablation 
sample introduction, J. Anal. Atom. Spectrom., 13, 135-140, 1998.

Tolocka, M. P., Lake, D. A., Johnston, M. V., and Wexler, A. S.: Number concentrations of fine and ultrafine particles containing metals, Atmos. Environ., 38, 3263-3273, 2004.

Triglav, J., van Elteren, J. T., and Šelih, V. S.: Basic modeling approach to optimize elemental imaging by laser ablation ICPMS, Anal. Chem., 82, 8153-8160, 2010.
Turšič, J., Podkrajšek, B., Grgić, I., Ctyroky, P., Berner, A., Dusek, U., and Hitzenberger R.: Chemical composition and hygroscopic properties of size-segregated aerosol particles collected at the Adriatic coast of Slovenia, Chemosphere, 63, 1193-1202, 2006. 